\title{
Classification of Igneous Rocks: Diorite vs. Syenite - a suggestion to avoid a contradiction
}

\author{
Maurizio Mazzucchelli \\ Dipartimento di Scienze Chimiche e Geologiche, Università di Modena e Reggio Emilia, Via Campi, 103, I-41125 Modena (Italy) \\ E-mail: maurizio.mazzucchelli@unimore.it
}

(Received: 05/11/2015; Accepted: 19/02/2016)

In the recommendations of the Sub-Commission on the Systematics of Igneous Rocks of the International Union of Geological Sciences, in the volume edited by R.W. Le Maitre (2002), there is an evident contradiction in the definition of the dioritic and syenitic plutonic rocks.

According to Le Maitre (2002) the parameters used for the modal classification of the plutonic rocks are: Q, A, P, F and M, where:

$\mathrm{Q}=$ quartz, tridymite, cristobalite;

$\mathbf{A}=$ alkali feldspar, including orthoclase, microcline, perthite, anorthoclase, sanidine and albitic plagioclase $\left(\mathbf{A n}_{\mathbf{0}}\right.$ to $\left.\mathbf{A n _ { 5 }}\right) ; \mathbf{P}=$ plagioclase $\left(\mathrm{An}_{\mathbf{5}}\right.$ to $\left.\mathbf{A n _ { 1 0 0 }}\right)$ and scapolite;

$\mathrm{F}=$ feldspathoids including nepheline, leucite, kalsilite, analcime, sodalite, nosean, haûyne, cancrinite and pseudoleucite;

$\mathrm{M}=$ mafic and related minerals, e.g. mica, amphibole, pyroxene olivine, opaque minerals, accessory minerals (e.g. zircon, apatite, titanite), epidote, allanite, garnet, melilite, monticellite, primary carbonate.

When a rock is defined as felsic, e.g. $M<90 \%$, the modal classification is based on the QAPF diagram (Streckeisen, 1973, Figs. 1 and 2). To use the QAPF classification, the modal amounts of $\mathrm{Q}, \mathrm{A}$, $\mathrm{P}$ and $\mathrm{F}$ must be known and recalculated so that their sum is $100 \%$.

When a rock plots in the following fields: 4, 9, 10, 13 and 14 (Fig. 1), the root names proposed by the classification are: diorite and gabbro (and anorthosite in field 10, with $\mathrm{M}<10 \%$ ). A Diorite is defined when plagioclase $=\mathbf{A} \mathbf{n}_{\mathbf{0}}$ to $\mathbf{A} \mathbf{n}_{\mathbf{5 0}}$, whereas a Gabbro has plagioclase $=A \mathbf{n}_{50}$ to $A \mathbf{n}_{100}$.

Therefore a contradiction arises whenever the composition of the plagioclase $=\mathbf{A} \mathbf{n}_{\mathbf{0}}$ to $A \mathbf{n}_{\mathbf{5}}$. From the definition of $\mathrm{A}$ and $\mathrm{P}$ reported above, the albitic plagioclase should be part of the parameter A and, correspondingly, the parameter $\mathrm{P}$ would be $=0$ (unless scapolite is present). Rocks containing albitic plagioclase $\left(\mathbf{A} \mathbf{n}_{0}\right.$ to $\mathbf{A} \mathbf{n}_{5}$ ) would therefore fall inevitably in the fields closer to the vertex A of the QAPF diagram (e.g. the rocks that are supposed to fall in the field 4 would plot within the field 2, those in the fields 9 and 10 in field 6 and those in the fields 13 and 14 in field 11).

This contradiction does not help in resolvingthe confusion in the classification of rocks manifested in several publications in various scientific journals. Cases of dioritic rocks defined as syenites and vice versa are not uncommon. Examples of the first case are reported in: (a) Stähle et al. (1990), where pegmatites without K-feldspar and containing plagioclase $=\mathrm{An}_{07}-\mathrm{An}_{11}$ are defined as mica syenites and nepheline syenites; (b) Stähle et al. (2001), where a dike consisting of hornblende and plagioclase $=\mathrm{An}_{08}-\mathrm{An}_{13}$ is defined as hornblende syenite; (c) Schaltegger et al. (2015), where zircon, biotite, plagioclasebearing pegmatites are defined as miaskitic nepheline syenite; the plagioclase composition $\left(\mathrm{An}_{06}-\mathrm{An}_{07}\right)$ of these samples is reported in Weiss et al. (2007). An example of the second case is reported in $\mathrm{Yu}$ et al. (2011) who describes albite diorite rocks for the Zhongjiu iron deposit, following the quite old quantitative mineralogical

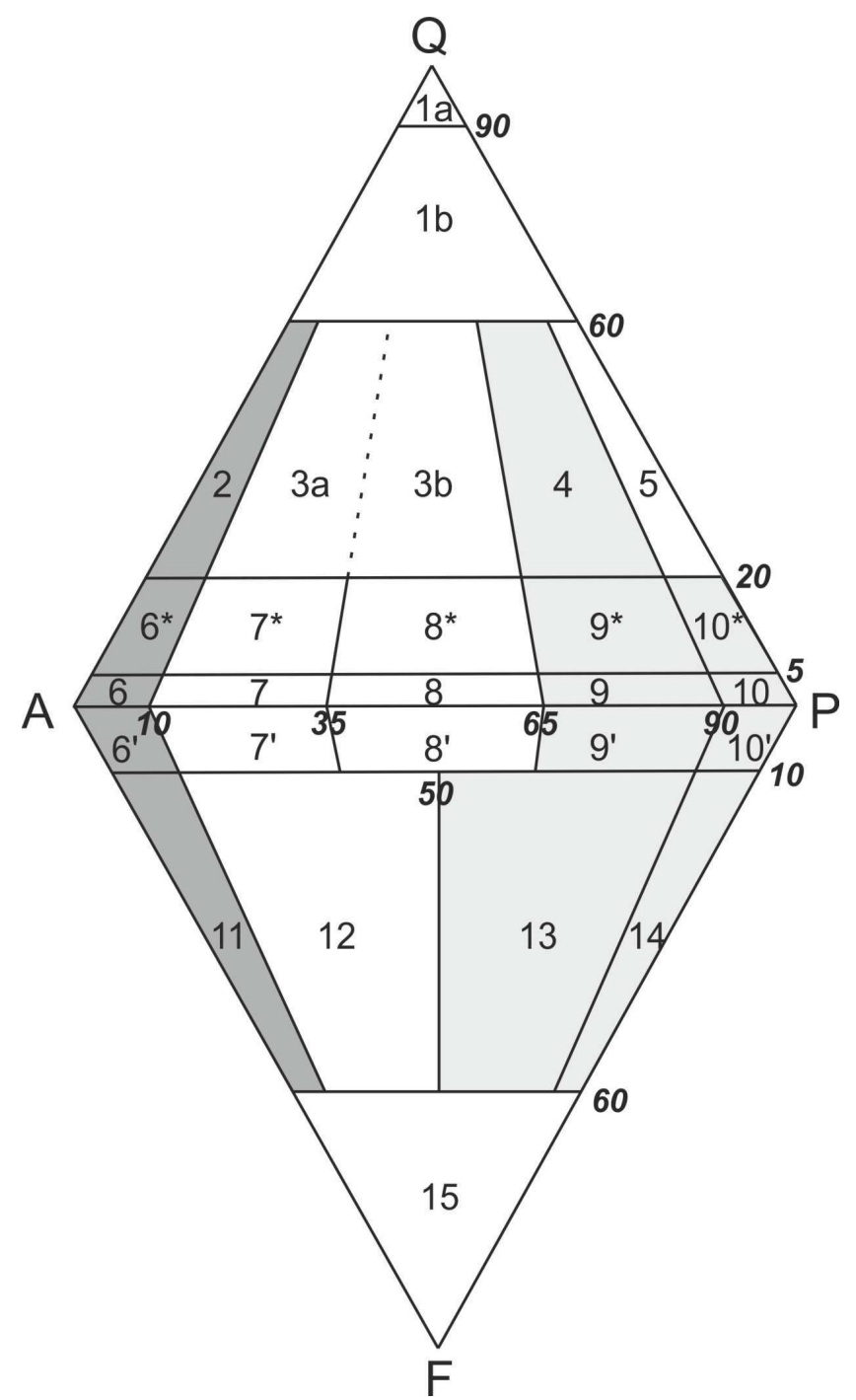

Figure 1. QAPF diagram with field numbers, after Le Maitre (2002). Light grey color $=$ Fields where both diorite and gabbro are root names: the dioritic and gabbroic rocks with plagioclase composition An > 5\% plot here; Dark grey color = Fields where the supposed dioritic rocks (considering the erroneous definition: plagioclase $=A n_{0}$ to $A n_{50}$ ) will plot if plagioclase composition An $<5 \%$ (and no scapolite is present). 


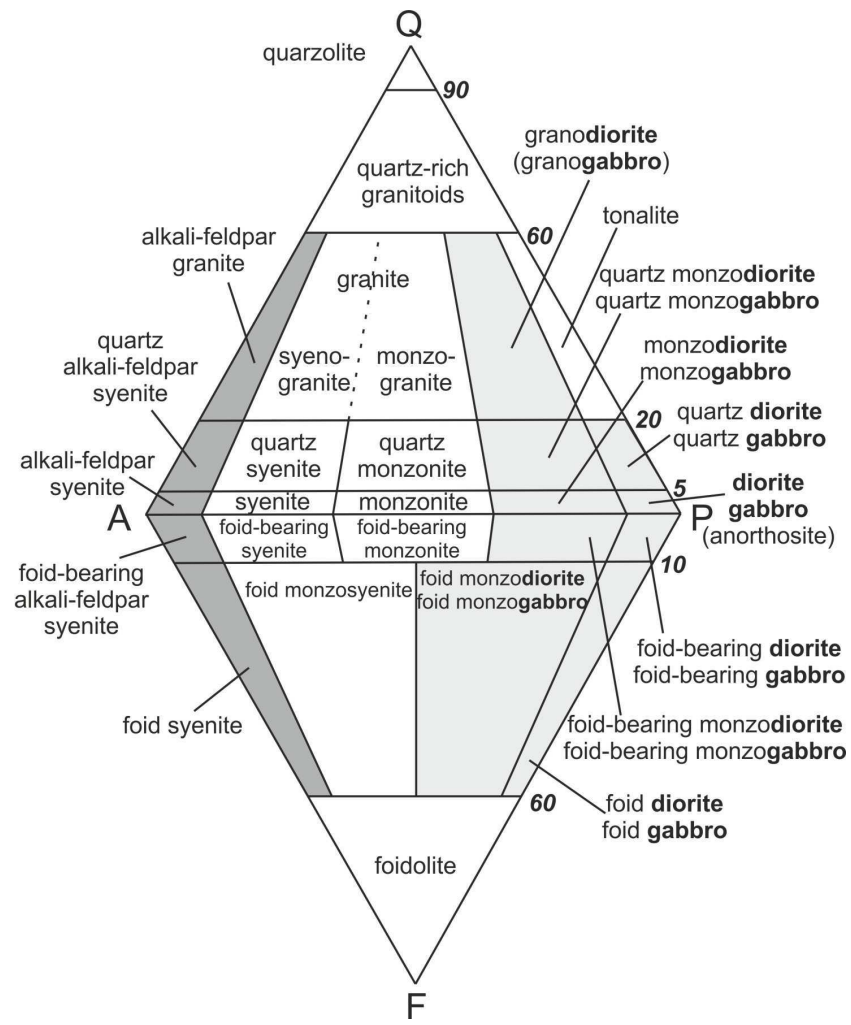

Figure 2. QAPF diagram with field names, after Le Maitre (2002). Light grey color $=$ Fields where both diorite and gabbro are root names: the dioritic and gabbroic rocks with plagioclase composition An $>5 \%$ plot here; Dark grey color = Fields where the supposed dioritic rocks (considering the erroneous definition: plagioclase $=$ $A n_{0} t o A n_{50}$ ) will plot if plagioclase composition An $<5 \%$ (and no scapolite is present).

classification of igneous rocks of Johannsen (1920), while these rocks in reality are syenites.

The suggestion proposed here is to amend the definition of the diorite root as follows:

A Diorite is defined when plagioclase $=\mathbf{A} \mathbf{n}_{\mathbf{5}}$ to $\mathbf{A} \mathbf{n}_{\mathbf{5 0}}$. This is also in accordance with the first definition of Streckeisen (1973), who only had place the limit between diorite and gabbro the composition $\mathrm{An}=50$, without setting the lower limit for the diorite root, as already implicit in the definition of the parameter A. Alternatively, the classification of plutonic rocks based on the chemical composition, as proposed by Bellieni et al. (1995), would be recommended.

Acknowledgements: This note benefited from constructive reviews by two anonymous reviewers. The Editor in Chief, Dr. Fareeduddin and the Handling Editor, Dr. Reimar Seltmann are also thanked.

\section{References}

Bellieni G., Justin Visentin E., Zanettin B. (1995) Use of the chemical TAS diagram (Total Alkali Silica) for classification of plutonic rocks: problems and suggestions. SocietàItaliana di Mineralogia e Petrologia, Plinius, 14, 49-52.

Le Maitre R.W. (Eds.) and I.U.G.S. Subcommission on the Systematics of Igneous Rocks. (2002) A classification of Igneous Rocks and Glossary of terms. Recommendations of the International Union of Geological Sciences. Subcommission on the Systematics of Igneous Rocks. Cambridge University Press, 236 p.

Schaltegger U., Ulianov A., Muntener O., Ovtcharova M., Peytcheva I., Vonlanthen P., Vennemann T.W., Antognini M., Girlanda F., (2015). Megacrystic zircon with planar fractures in miaskite-type nepheline pegmatites formed at high pressures in the lower crust (Ivrea Zone, southern Alps, Switzerland). American Mineralogist, 100, 83-94.

Stälhe, V., Frenzel, G., Kober, B., Michard, A., Puchelt, H., Schneider, W. (1990). Zircon syenite pegmatites in the Finero peridotite (Ivrea Zone): evidence for a syenite from a mantle source. Earth and Planetary Science Letters, 101, 196-205.

Stähle, V., Frenzel, G., Hess, J. C., Saupé, F., Schmidt, S. Th., Schneider, W., 2001. Permian metabasalt and Triassic alkaline dykes in the Northern Ivrea Zone: clues to the post-Variscan geodynamic evolution of the Southern Alps. Schweizerische Mineralogische und PetrographischeMitteilungen, 81, 1-21.

Streckeisen A. (1973) Plutonic rocks. Classificationand nomenclature recommendedby the IUGS Subcommission on the Systematics of Igneous Rocks. Geotimes, 18 (10), 26-30.

Weiss S., Fehr T., Ansermet S., Meisser N., Pakhomovsky Y.A., (2007) ZirkonführemdeNephelin-pegmatite imCentovalli, Südschweiz: Struktur, MineralogieundKristallisationsfolge. Lapis 10, 24-30.

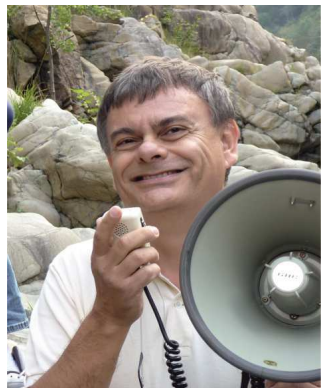

Maurizio Mazzucchelli is Full Professor in the Department of Chemical and Geological Sciences of the Modena and Reggio Emilia University (Italy). His work has focused on deep and intermediate crust (Ivrea-Verbano Zone), continental anorogenic magmatism (Southern America), continental lithospheric mantle. Currently he is dealing with fluid and melt percolation processes through mantle peridotite matrix, the role of mantle heterogeneity in subcontinental peridotite massifs on the genesis of basic magma, mass transfer process of fluids in hydrated and carbonated mantle rocks from supra-subduction settings, growth mechanism of mafic-ultramafic layered complex, mafic dike swarms as key markers of their mantle source and the geodynamic environment. 